\title{
Case of Resistance to Thyroid hormones (RTH) with relatively rare mutation in Thyroid Hormones Receptor (THR)
}

\author{
Hind Ahmed ${ }^{1}$, Khalid Khamis ${ }^{1}$, and Mohanad Ahmed ${ }^{2}$ \\ ${ }^{1}$ Hamad Medical Corporation \\ ${ }^{2}$ Affiliation not available
}

January 13, 2021

\begin{abstract}
This is an article that share clinical manifestation and diagnosis of patient with THR mutation, who found to have very rare mutation in THR-beta.
\end{abstract}

\section{Introduction}

Thyroid hormones are produced in response of the thyroid gland to thyroid stimulating hormone (TSH) secreted from anterior pituitary gland. Circulating thyroid hormones in forms of T4 and T3 enter cells by diffusion and, in some tissues, such as the thyroid and brain, by active transport [1]. T3 is the active form of thyroid hormones which will also be available to cells from local conversion of T4 into T3 in side cells them self. This locally produced T3 can leave the cell and binds to T3 receptors in other tissues. In humans, approximately 80 percent of extrathyroidal T3 produced from T4 is produced intracellularly $[2,3]$. Intracellular T3 binds to nuclear receptor called Thyroid Receptor (TR). T3-TR complexes then bind to regulatory regions contained in the genes that are responsive to thyroid hormone and exerts its action [4].

There are two TRs, alpha (THRa) and beta (THRb) $[4,5]$. THRa is mainly found in bones, intestine nervous system and heart while THRb is found mainly in retina, ear, heart, nervous system and it's the main regulator of the negative feedback on pituitary thyroid axis [6].

Most patients diagnosed with RTH are found to have mutations in THRb with variant mutations had been described. However, recently some patients are found to have mutations in THRa [6]. Clinical manifestation depends on the receptor affected and the magnitude of the resistance. There is no specific treatment for RTH and multiple modalities of treatment have been found in reviewing the literature.

In this article we are reporting case of RTH, confirmed with genetic testing and found to have sequence variant mutation that is not well described due to absence of genetic conclusive evidence.

\section{Case Report/Case Presentation}

Our case is 35 years old female known to have type 2 Diabetes Mellitus on metformin 1 gm daily. In 2014, the patient presented with fatigue and weight gain. Work up showed TSH $23 \mathrm{Miu} / 1$ (0.5 to $5.5 \mathrm{Miu} / \mathrm{l}$ ) and T4 of $15 \mathrm{Miu} / \mathrm{l}$ (9 to $21 \mathrm{Miu} / \mathrm{l})$. The patient was diagnosed with subclinical hypothyroidism and started on levothyroxine treatment. Starting dose was $25 \mathrm{mcg}$ daily and the patient was followed to monitor her symptoms and TSH level.

In next follow up appointments, the patient reported some improvement in her symptoms. however, her TSH level was persistently elevated. Thyroxin dose was gradually built up till a dose of $100 \mathrm{mcg}$ was reached over 
4 years period but TSH level wasn't inhibited. Other labs including complete blood count, renal function, liver function and lipid profile were within normal limits.

Appointment in November 2018, TSH was $20 \mathrm{miu} / \mathrm{L}$. levothyroxine dose was subsequently increased to 150 mcg daily. Few weeks later, the patient reported hyperthyroid symptoms including insomnia, tremors and palpitation. Repeated thyroid function test showed TSH of $6.6 \mathrm{miu} / \mathrm{L}$ and T4 level was significantly high $(30 \mathrm{mic} / \mathrm{L})$. the dose was reduced to $100 \mathrm{mcg}$ and antibodies were requested.

Next appointment following reduction of levothyroxine dose, her insomnia and palpitations improved. Repeated labs showed TSH $34 \mathrm{miu} / \mathrm{L}, \mathrm{T} 417 \mathrm{miu} / \mathrm{L}$, antithyroid peroxidase antibody $>600 \mathrm{IU} / \mathrm{ml}(0$ to 34 $\mathrm{IU} / \mathrm{ml}$ ), antithyroglobin antibody $489 \mathrm{IU} / \mathrm{ml}(0$ to $115 \mathrm{IU} / \mathrm{ml})$ and $\mathrm{TSH}$ receptor antibody $0.8 \mathrm{IU} / \mathrm{L}$ (0 to $1.7 \mathrm{IU} / \mathrm{L})$.Figure 1 showed TSH, T4 and T3 throughout treatment with various doses of levothyroxine from time of diagnosis ( 2013) till 2020,

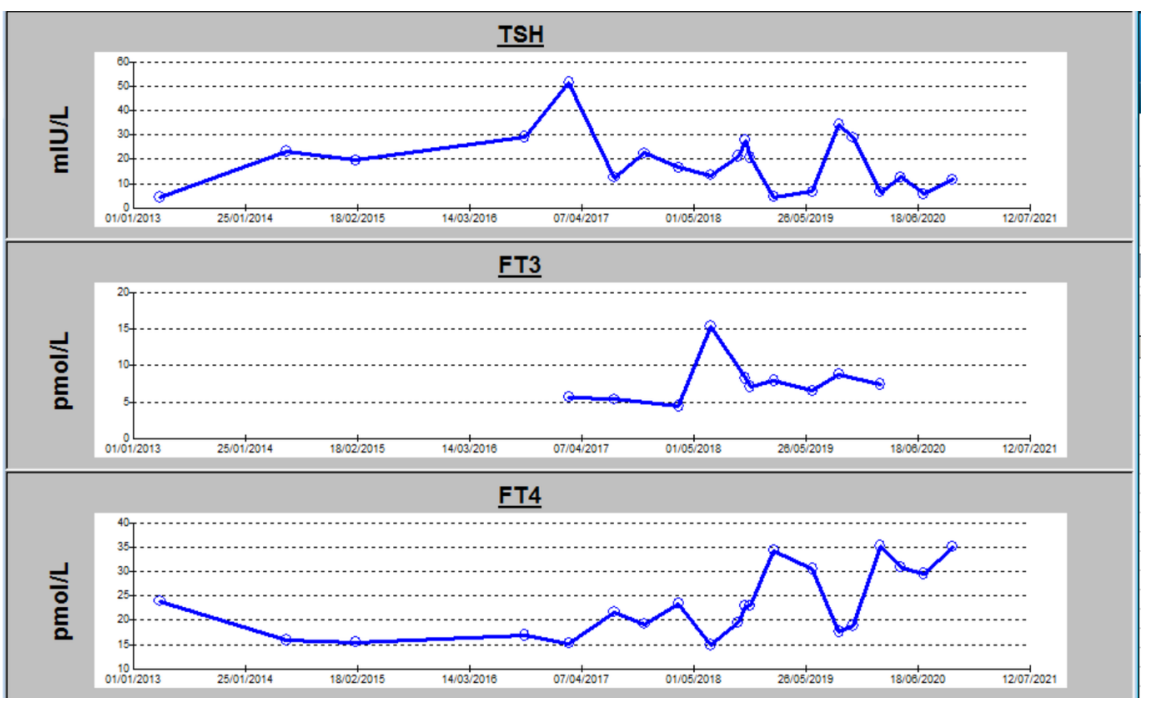

Figure 1. TSH, T4 and T3 level from diagnosis throughout various thyroxin treatment doses till 2020.

Given the values of high TSH not suppressed by levothyroxine treatment, we started to think about alternative diagnosis that leads to persistent elevation of TSH for example TSH secreting tumor and TSH resistance. Magnetic Resonance Images (MRI) of the pituitary gland was ordered to exclude TSH secreting pituitary tumor which revealed normal pituitary gland size. See figure 2. 


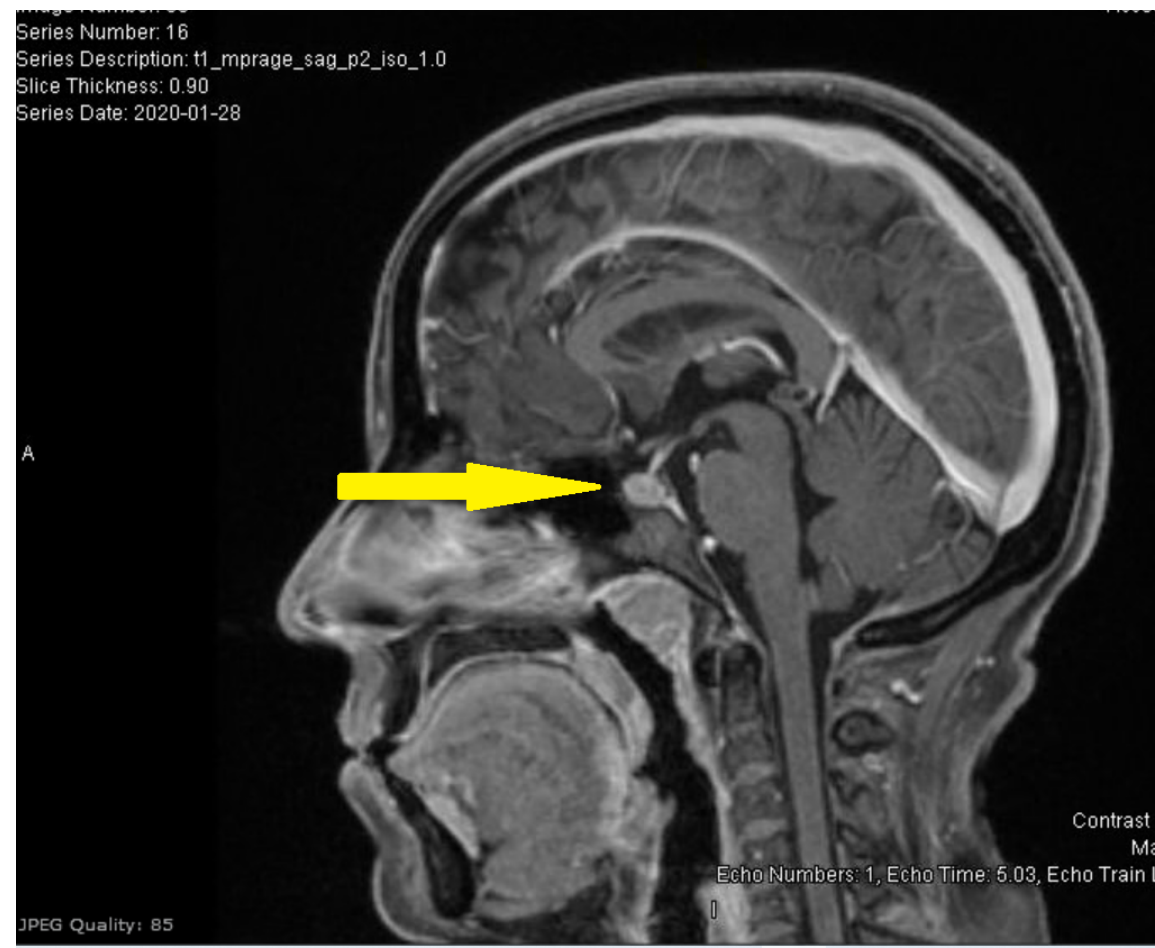

Figure 2. arrow pointing to normal pituitary gland size.

Alpha subunit of pituitary gland which is used as a tumor marker for anterior pituitary gland tumors was also ordered, it was found to be $0.2 \mathrm{ng} / \mathrm{ml}$ (normal $<1.8 \mathrm{ng} / \mathrm{ml}$ ).

Then genetic test was ordered to establish a diagnosis of TSH resistance which confirmed TSH resistance through THRB gene. see figure 3 .

MOLECULAR GENETICS REPORT:

Thyroid Hormone Resistance via the THRB Gene

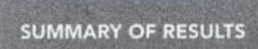

Heterozygous for a Variant of Uncertain Significance in THRB

\begin{tabular}{|l|c|c|c|c|c|c|}
\hline \multicolumn{1}{|c|}{$\begin{array}{c}\text { Gene, } \\
\text { Transcript }\end{array}$} & $\begin{array}{c}\text { Mode of } \\
\text { Inheritance, } \\
\text { Gene OMIM }\end{array}$ & $\begin{array}{c}\text { DNA Variations, } \\
\text { Predicted Effects, } \\
\text { Zygosity }\end{array}$ & ClinVar ID & $\begin{array}{c}\text { Highest Allele } \\
\text { Frequency in a } \\
\text { gnomAD Population }\end{array}$ & $\begin{array}{c}\text { In Sillico } \\
\text { Missonse } \\
\text { Predictions }\end{array}$ & Interpretation \\
\hline $\begin{array}{l}\text { THRB } \\
\text { NM_001252634.1 }\end{array}$ & $\begin{array}{c}\text { AD. AR. } \\
190160\end{array}$ & $\begin{array}{c}\text { C.1147C>T, } \\
\text { p.Ar363Cys, } \\
\text { Heterozygous }\end{array}$ & 619915 & Not Present & Damaging & UNCERTAIN \\
\hline
\end{tabular}

Mode of Inneritance: Autosomal Dominant=AD, Autosomal Recessive=AR, $X$-Linked=XL ClinVar ID: Variant accession (www. ncbininm.nin. govidinvar)

GnomAD: Alele Frequency registered in a large population catabase (gnonad.broadinstitute.org). Value listed is the highest allele frequency reported within one of seven population categories recognized in gnoma vi.2. (The "Other population is excuded)

RESULTS AND INTERPRETATIONS: This patient is heterozygous in the THRB gene for a sequence variant designated c. $1147 \mathrm{C}>\mathrm{T}$, which is predicted to result in the amino acid substitution p.Arg383Cys.

Fgure 3. Molecular genetic report confirming THS resistance via THRB gene.

The diagnosis was explained to the patient and levothyroxine dose was reduced gradually to maintain the lowest dose that is sufficient to prevent symptoms with subsequent follow up to depend on T4 level and the patient symptoms not on TSH level. 


\section{Discussion:}

Resistance to thyroid hormone was first described as a clinical entity in 1967 [7]. Subsequent studies about the molecular pathogenesis of this syndrome identified mutations in the region of the gene that encodes the ligand-binding domain of THRb. Interestingly, patients with mutations in THR $a$ were not identified until 2012 [6]. Our patient in this article was found to have mutation in THRb same as majority of the patients described in the literature.

Patients with RTHb may have some symptoms or signs of hypothyroidism or hyperthyroidism, but these are variable and, when present, often inconstant. They frequently have elevated thyroid hormones level, high or normal TSH and goiter which suggest the importance of THRb in feedback of hypothalamic pituitary axis [6]. In contrast, patients with RTHa present with musculoskeletal and gastrointestinal abnormalities. They usually have near normal thyroid function due to lack of THRa contribution in feedback on hypothalamic pituitary axis $[8,9]$. Our patient initially presented with symptoms of hypothyroidism including weight gain and generalized fatigability in addition to high TSH which is consistent to typical presentation found in the literature. However, she had normal T3 and T4 which is not usually typical in presentation of RTHb that made our initial impression to be subclinical hypothyroidism.

To date, more than 100 THRB mutations have been reported among RTH patients. Most mutations substitute a single amino-acid residue in the ligand-binding domain [10]. The most unique part in our case is found in genetic study, which confirmed that the patient is heterozygous in THRb gene for sequence variant designatedc.1147C $>\mathbf{T}$, which is predicted to result in amino acid substitution p.Arg383Cys. this variant appears to have been reported in French patient with thyroid hormone resistant [11]. It was also reported in another affected individual but was inherited from apparently unaffected father [10]. Another variant affecting the same amino acid have also been reported in patient with thyroid hormone resistance [12].

While we suspect this variant could be pathogenic, at this time clinical significance of this variant is uncertain due to lack of conclusive functional and genetic evidence.

Looking in literature about associations. We found that RTH-beta is associated with an increased risk for autoimmune thyroid disease [13]. Thus, the presence of antibodies to thyroid peroxidase and thyroglobulin should not detract from the investigation of RTH-beta if thyroid function tests suggest this possibility. Both antibodies were found to be positive in our patient, so now we are closely monitoring her for development of other autoimmune disease.

\section{Conclusion;}

Our case represent aid to other collegues in clinical suspicsion and diagnosing cases of RTH in addition to differentiation of RTH-alpha and RTH-beta. However the most interresting part in our case is the genetic study which revelaed a rare mutation in thyroid hormone receptor beta which have been only reported in very few cases before(heterozygous in THRb gene for sequence variant designated $\mathbf{c . 1 1 4 7 C}>\mathrm{T}$, which is predicted to result in amino acid substitution p.Arg383Cys ). While we suspect this variant could be pathogenic, at this time clinical significance of this variant is uncertain due to lack of conclusive functional and genetic evidence.

\section{Statements}

\section{Acknowledgement}

Authors acknowledge internal medicine residency program for scientific support and Qatar National Library for Financial support

Statement of Ethics Case approved by HMC medical research center and Subjects have given his written informed consent to publish her case.

\section{Funding statement:}

This research is funded by Qatar National library 
Disclosure Statement

All authors declared no conflict of interest.

Author Contributions

1. Mohanad Ahmed: Corresponding author, Case writing, patient clinical follow up, data collection and analysis , submission to journal.

2. Khalid Hassan: over all supervision, data collection patient clinical follow up.

3. Hind Ahmed: patient clinical follow up and contact with genetic lab.

\section{References (Numerical)}

1. Bernal J, Guadaño-Ferraz A, Morte B. Thyroid hormone transporters-functions and clinical implications. Nat Rev Endocrinol. 2015 Jul;11(7):406-17. doi: 10.1038/nrendo.2015.66. Epub 2015 May 5. Erratum in: Nat Rev Endocrinol. 2015 Sep;11(9):506. Erratum in: Nat Rev Endocrinol. 2015 Dec;11(12):690. PMID: 25942657.

2. Marsili A, Zavacki AM, Harney JW, Larsen PR. Physiological role and regulation of iodothyronine deiodinases: a 2011 update. J Endocrinol Invest. 2011 May;34(5):395-407. doi: 10.1007/BF03347465. Epub 2011 Mar 21. PMID: 21427525; PMCID: PMC3687787.

3. Gereben B, Zavacki AM, Ribich S, Kim BW, Huang SA, Simonides WS, Zeöld A, Bianco AC. Cellular and molecular basis of deiodinase-regulated thyroid hormone signaling. Endocr Rev. 2008 Dec;29(7):898-938. doi: 10.1210/er.2008-0019. Epub 2008 Sep 24. PMID: 18815314; PMCID: PMC2647704.

4. Brent GA. Mechanisms of thyroid hormone action. J Clin Invest. 2012 Sep;122(9):3035-43. doi: 10.1172/JCI60047. Epub 2012 Sep 4. PMID: 22945636; PMCID: PMC3433956.

5. Mendoza A, Hollenberg AN. New insights into thyroid hormone action. Pharmacol Ther. 2017 May;173:135-145. doi: 10.1016/j.pharmthera.2017.02.012. Epub 2017 Feb 4. PMID: 28174093; PMCID: PMC5407910.

6. Ortiga-Carvalho TM, Sidhaye AR, Wondisford FE. Thyroid hormone receptors and resistance to thyroid hormone disorders. Nat Rev Endocrinol. 2014 Oct;10(10):582-91. doi: 10.1038/nrendo.2014.143. Epub 2014 Aug 19. PMID: 25135573; PMCID: PMC4578869.

7. Refetoff S, DeWind LT, DeGroot LJ. Familial syndrome combining deaf-mutism, stuppled epiphyses, goiter and abnormally high PBI: possible target organ refractoriness to thyroid hormone. J Clin Endocrinol Metab. 1967;27:279-294.

8. Bochukova E, et al. A mutation in the thyroid hormone receptor $\alpha$ gene. N Engl J Med. 2012;366:243249 .

9. Refetoff S, Dumitrescu AM. Syndromes of reduced sensitivity to thyroid hormone: genetic defects in hormone receptors, cell transporters and deiodination. Best Pract Res Clin Endocrinol Metab. 2007;21:277-305.

10. Narumi S, Cho H, Tamada I, Kozu Y, Tsuchiya T, Nagai T, Hasegawa T. One Novel and Two Recurrent THRB Mutations Associated with Resistance to Thyroid Hormone: Structure-based Computational Mutation Prediction. Clin Pediatr Endocrinol. 2010 Oct;19(4):91-9. doi: 10.1297/cpe.19.91. Epub 2010 Dec 29. PMID: 23926384; PMCID: PMC3687625.

11. Margotat A, Sarkissian G, Malezet-Desmoulins C, Peyrol N, Vlaeminck Guillem V, Wémeau JL, Torresani J. Identification de huit nouvelles mutations dans le gène c-erbAB chez des patients atteints de résistance aux hormones thyrö̈diennes [Identification of eight new mutations in the c-erbAB gene of patients with resistance to thyroid hormone]. Ann Endocrinol (Paris). 2001 Jun;62(3):220-5. French. PMID: 11458173.

12. Clifton-Bligh RJ, de Zegher F, Wagner RL, Collingwood TN, Francois I, Van Helvoirt M, Fletterick RJ, Chatterjee VK. A novel TR beta mutation (R383H) in resistance to thyroid hormone syndrome predominantly impairs corepressor release and negative transcriptional regulation. Mol Endocrinol. 1998 May;12(5):609-21. doi: 10.1210/mend.12.5.0113. PMID: 9605924.

13. Barkoff MS, Kocherginsky M, Anselmo J, Weiss RE, Refetoff S. Autoimmunity in patients with resi- 
stance to thyroid hormone. J Clin Endocrinol Metab. 2010 Jul;95(7):3189-93. doi: 10.1210/jc.2009-2179. Epub 2010 May 5. PMID: 20444926; PMCID: PMC2928894. 